Journal of Applied Finance \& Banking, Vol. 11, No. 1, 2021, 19-40

ISSN: $1792-6580$ (print version), 1792-6599 (online)

https://doi.org/10.47260/jafb/1112

Scientific Press International Limited

\title{
Exchange Rate Determination: The Portfolio-Balance Approach
}

\author{
Dr. Ioannis N. Kallianiotis ${ }^{1}$
}

\begin{abstract}
The portfolio-balance approach to exchange rate determination is part of the Asset Market Models and is largely attributed to economists after 1973 when the exchange rate became flexible (market determined). This article first introduces the setting of the model embedded in the portfolio balance approach that encompasses two assets (money and bonds), which deviates a little from the models and approaches used for the monetary approach to the balance of payment, the overshooting model, and from the associated market equilibria. The effects of monetary policy, of current account, and of wealth under the portfolio-balance approach are examined, here, theoretically and empirically. The current econometric results show that the exchange rate is determined by the foreign bonds, the domestic interest rate, and the foreign interest rate.
\end{abstract}

JEL classification numbers: F31, F47, E52, E41, C52, E21, E43.

Keywords: Foreign Exchange, Forecasting and Simulation, Monetary Policy, Demand for Money, Model Evaluation and Testing, Consumption and Saving, Interest Rates.

\footnotetext{
${ }^{1}$ Economics/Finance Department, The Arthur J. Kania School of Management, University of Scranton, Scranton, PA 18510-4602.
}

Article Info: Received: September 21, 2020. Revised: October 8, 2020.

Published online: October 13, 2020. 


\section{Introduction}

The monetary approach focuses only on a single-asset (money). The portfolio balance approach deals with multi-assets and integrates the analysis of the exchange rate behavior with these other financial assets (bonds, stocks, etc.). This second approach of exchange rate determination allows the current account imbalances ( $-C A=K A$ ) to affect the exchange rate [where, $C A=$ the current account and $K A=$ the capital account]. Thus, the portfolio balance model contains features provided by the Monetary Approach and the Balance of Payment Approach. Residents of both countries hold assets issued by these two countries. Domestic residents wish to hold a greater proportion of their wealth in domestic assets and foreign residents wish to hold a greater proportion in foreign assets ("perfect local habitat"). The current account will redistribute world wealth in such a way as to raise net world demand for the surplus country's assets; thus, raising the price of its currency.

The Portfolio Balance Approach is a theory of exchange determination, where the economic agents have to choose from a portfolio of domestic and foreign assets. These assets may be in the form of bonds or money; money has zero return and bonds have a positive expected return, which have arbitrage opportunities. These opportunities among countries help to determine exchange rates.

Four types of assets are available to the economic agents. First, is cash, Money in both countries $\left(M, M^{*}\right)$ that does not yield any interest (actually has a negative real return, $r_{M}=-\pi^{e}$ ), but is useful for the purpose of purchasing products (medium of exchange). Second, are domestic Bonds $(B)$ that yield a nominal interest rate, $i$ and foreign Bonds $\left(B^{*}\right)$ yield an interest rate, $i^{*}$. The central banks and the governments provide all the four types of assets that are mentioned, here. The household sector in each country makes a choice from these three types of assets in domestic economy $\left(M, B, B^{*}\right)$ and in the foreign $\left(M^{*}, B, B^{*}\right)$ to form the portfolia. The nominal wealth of an individual in the domestic country is:

$$
W=B+S B^{*}+M
$$

The real wealth can be determined by dividing both sides by the price level,

$$
\frac{W}{P}=\frac{B}{P}+\frac{S B^{*}}{P}+\frac{M}{P}
$$

The portfolio balance approach determines the equilibrium exchange rate, domestic and international interest rate that would clear the domestic bond market, money market and the foreign bond market. 


\subsection{Money Market}

Let's assume that the dollar suffers a 10\% depreciation ( $S \uparrow$ ). This would increase the foreign asset value by $10 \%$. In turn, it causes an increase in the total wealth that would lead to an expansion in the demand for all kinds asset, which would also include money. The wealth effect of this depreciation in currency would lead to a rise in the domestic interest rate $(i \uparrow)$. With all parameters fixed, a depreciation of the currency $(S \uparrow)$ is accompanied by a rise in the money market interest rate $(i \uparrow)$.

\subsection{Domestic Bond Market}

With this dollar depreciation ( $S \uparrow$ ), the demand of domestic bonds will increase ( $\left.B^{d} \uparrow\right)$. This would result to an increase in bond prices $\left(P_{B} \uparrow\right)$ and in a reduction of interest rate $(i \downarrow)$. Domestic and foreign bonds have different risk exposures although they may be a part of the same portfolio.

\subsection{Foreign Bond Market}

In response to $10 \%$ dollar depreciation $(S \uparrow)$ the supply of foreign bonds increases, eq. (2). Due to the wealth effect the demand for foreign bonds also rises $\left(B^{* d} \uparrow\right)$, their prices $\left(P_{B^{*}} \uparrow\right)$ will go up and their return will fall $\left(i^{*} \downarrow\right)$. Then, keeping all parameters fixed, the depreciation of the currency would lead to a fall in the domestic interest rate via the foreign bond market. The portfolio balance approach gives the equilibriums interest rate, both domestic and foreign as well as the exchange rate that would clear all the three markets, domestic money and bond market and foreign bond market. 
The correlation between current account deficits $\left(C A_{t}\right)$ and exchange rates $\left(s_{t}\right)$ has been undeniably strong $\left(\rho_{C A, s}>0\right)$, Figure $1 .^{2}$ The current account developments have been largely dominated by imports of oil and for small countries, except oil, by imports of industrial and manufacturing products. ${ }^{3}$

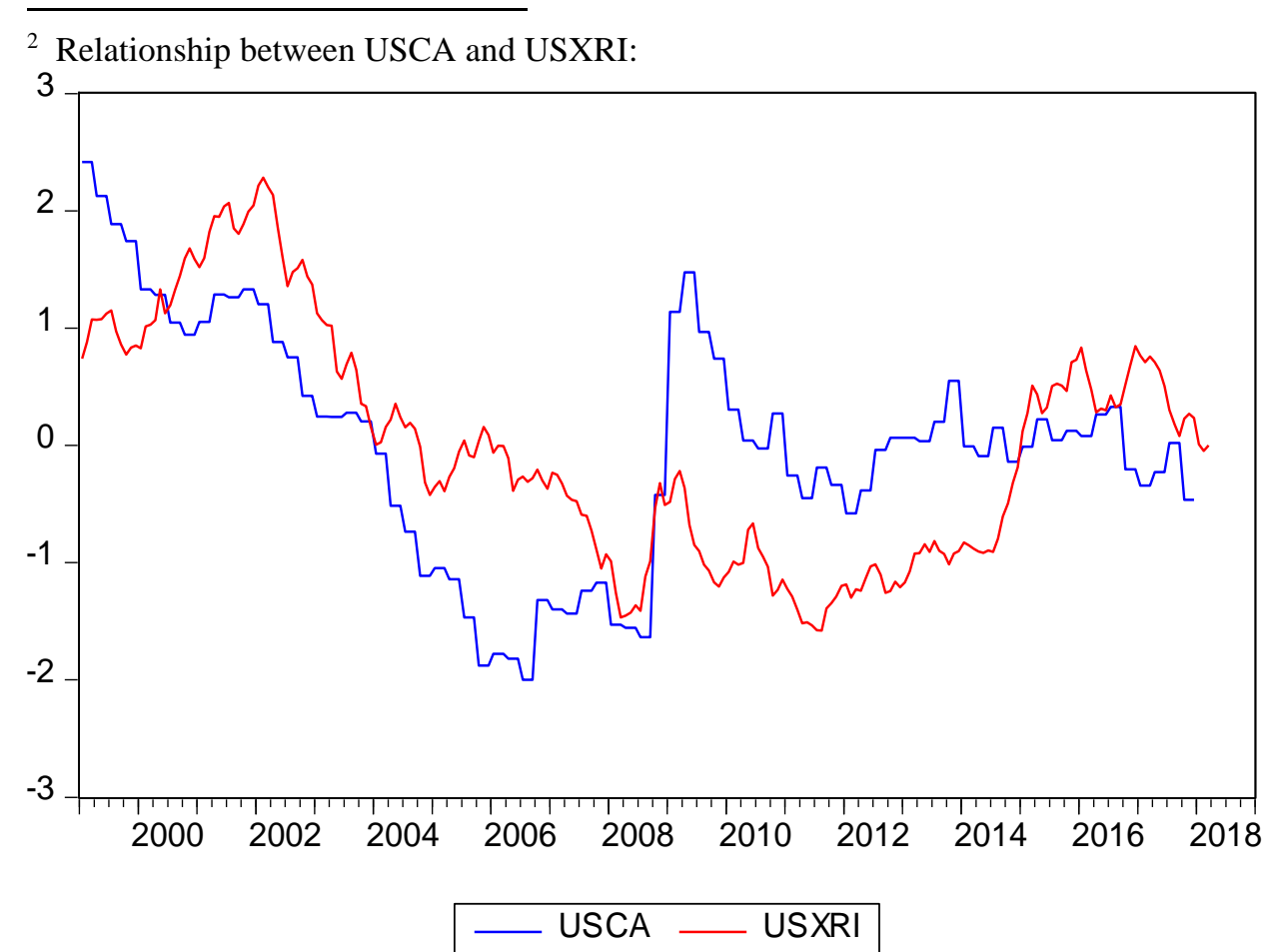

Figure 1: Current account and U.S. exchange rate index

Note: USCA $=$ U.S. current account, USXRI $=$ U.S. exchange rate index, $\rho_{\text {USCA,USXRI }}=+0.508$ and $\quad U S X R I \Rightarrow U S C A \quad(6$ lags $) \quad F=2.449^{* *}$.

Source: Economagic.com

3 The U.S. has enormous current account deficit: The United States has a $\$ 611$ billion deficit with its top five trading partners: (1) with China: \$346 billion, Mexico: $\$ 102$ billion, Japan: $\$ 69$ billion, Germany: $\$ 67$ billion, and Canada: $\$ 27$ billion. Total top 5: \$611 billion, with 2019. See, https://www.thebalance.com/u-s-trade-deficit-causes-effects-trade-partners-3306276 
As the world oil trade is done in U.S. dollars, a sharp increase in world oil prices raises the demand for the dollar at the expense of the other currencies (euro, yen, pound, etc.), Figure 2. ${ }^{4}$

4 The price of oil from 1950 to 2018 has a mean value of $\left(\bar{P}_{o i l}=\$ 26.05\right)$ per barrel and a standard deviation of ( $\sigma_{P_{\text {oil }}}= \pm \$ 28.10$ ); its minimum price was $\$ 2.57$ and its maximum price was $\$ 144.15$ (July 2008). With September 2018, it was $\$ 70.23$ per barrel, on April 8, 2019, it was $\$ 63.08 /$ barrel, and on September 14, 2020, it had fell to $\$ 37.26 /$ barrel. The increase of its price (from 1950-2008) was $5,509 \%$ or $94.98 \%$ per annum, which has contributed to the global inflation, risk, and recessions. (Economagic.com).

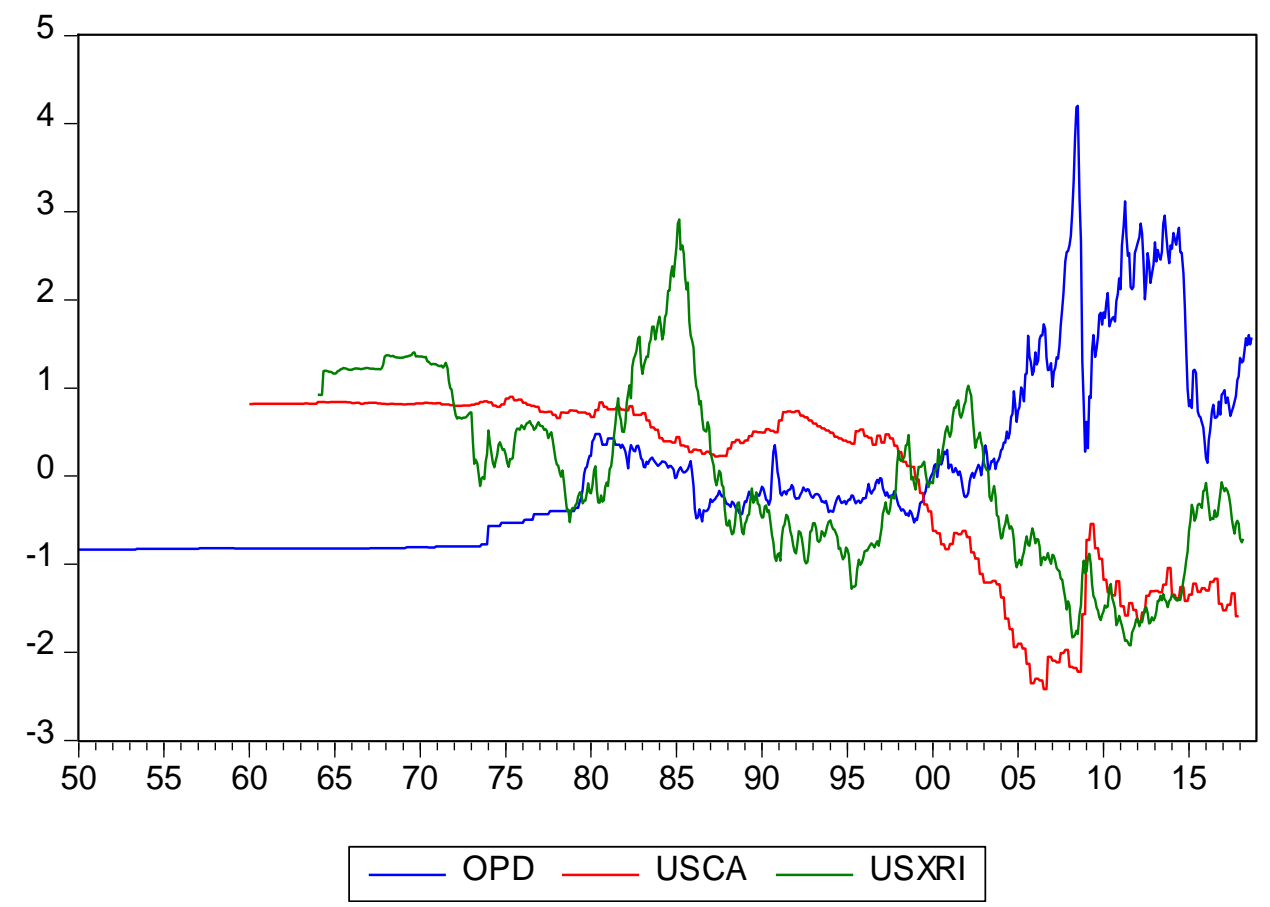

Figure 2: Price of oil, current account, and U.S. exchange rate index

Note: $O P D=$ oil price domestic (Price of West Texas Intermediate Crude), USCA = U.S. current account, $U S X R I=U . S$. exchange rate index $(F C / \$), \quad \rho_{O P D, U S C A}=-0.810$ and

$$
\begin{aligned}
& O P D \Rightarrow \text { USCA } \quad \text { (2 lags) } \quad F=19.223^{* *} ; \quad \rho_{U S X R I, O P D}=-0.681 \text { and } \\
& U S X R I \Rightarrow \text { OPD } \quad \text { (2 lags) } \quad F=2.607^{*} \text {. }
\end{aligned}
$$

An OLS estimation gives the following results:

$$
\begin{aligned}
& \text { USXRI }_{t}=103.417^{\text {**** }}-0.110^{\text {**** }} \text { OPD }+0.016^{\text {**** }} U S C A_{t}+1.660^{\text {**** }} \varepsilon_{t-1}+\ldots+0.286^{\text {**** }} \varepsilon_{t-7} \\
& \begin{array}{lllll}
(0.947) & (0.020) & (0.003) & (0.036)
\end{array}
\end{aligned}
$$

$R^{2}=0.985, \quad S E R=1.753, \quad F=4,207.956, \quad D-W=1.811, \quad N=648$ 
On the other hand, some economists argue that the huge U.S. national debt, the Middle East crises, and the easy money policy of the Fed for over seven years (December 16, 2008-December 16, 2015) and (March 15, 2020-present) ${ }^{5}$ had depreciated the dollar (Figures 1 and 2).

5 See, Kallianiotis (2019b). Also, http://www.fedprimerate.com/fedfundsrate/federal funds_rate history.htm 


\section{Current Account and Wealth}

The release by the U.S. government of unexpected figures on the trade balance and the current account appear to have large immediate "announcement effects" on the exchange rate (dollar depreciates or appreciates depending on "bad" or "good" news). The current account figures reveal information about shifts in the long run terms of trade.

Of course, the important point is that only the unexpected component $\left(C A^{u}\right)$ of the current account ( $\left.C A=C A^{e}+C A^{u}\right)$ has a large effect; the expected component $\left(C A^{e}\right)$ has already been taken into account by the foreign exchange market, ${ }^{6}$ Figure 3.

6 The Figure of the decomposition of the CA and the Leas Square Estimation of the USXRI on the OPD, $\mathrm{USCA}^{\mathrm{e}}$, and $\mathrm{USCA}^{\mathrm{u}}$ are:

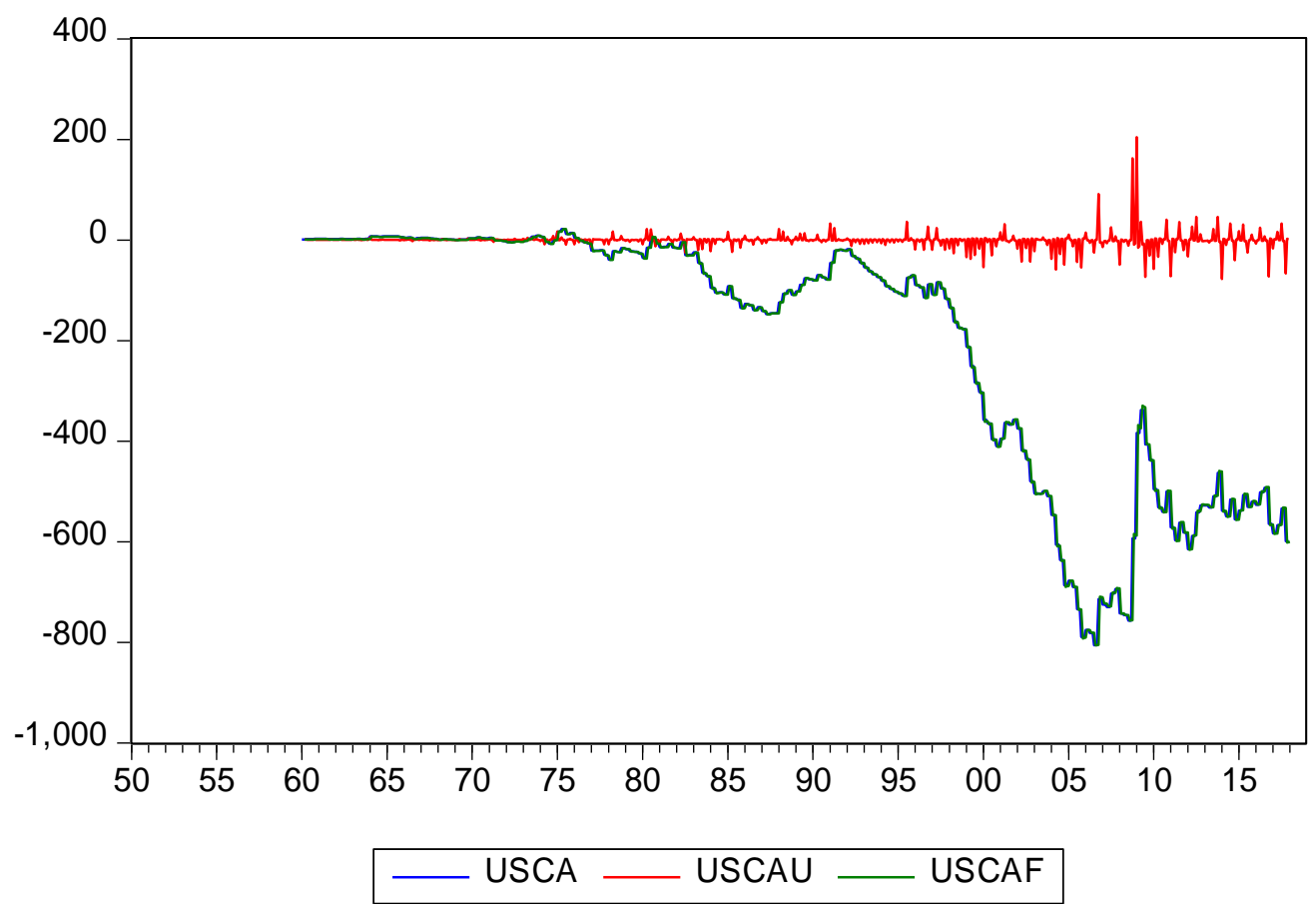

Figure 3: U.S. current account, expected current account, and unexpected current account

Note: $U S C A=U . S$. current account, USCAU $=$ the unexpected part of the U.S. current account, and USCAF $=$ the expected current account.

An OLS estimation gives the following results:

$$
\begin{aligned}
& \text { USXRI }_{t}=104.319^{\text {*** }}-0.089^{\text {**** }} \text { OPD } D_{t}+0.023^{\text {*** }} U S C A F_{t}+0.014^{\text {**** }} U S C A U_{t}+1.668^{\text {**** }} \varepsilon_{t-1}+ \\
& \begin{array}{llll}
(1.006) & (0.021) & (0.003) & (0.003)
\end{array} \\
& \ldots+0.293^{* * * *} \varepsilon_{t-7} \\
& \text { (0.036) } \\
& R=0.985, \quad S E R=1.736, \quad F=3,905.902, \quad D-W=1.808, \quad N=648
\end{aligned}
$$


The decomposition of the current account is written as,

$$
C A_{t+1}=C A_{t+1}^{e}+C A_{t+1}^{u}
$$

where, $\quad C A_{t+1}=$ the actual current account balance, $C A_{t+1}^{e}=$ the expected current account balance based on information today $\left[C A_{t+1}^{e}=E\left(C A_{t+1} \mid I_{t}\right)\right]$, and $C A_{t+1}^{u}=$ the unexpected part of the current account balance, the "surprise", the "news", the risky part of the $C A_{t+1}$.

In addition, a current account surplus is a transfer of wealth $(W)$ from foreign residents to domestic residents (and a transfer of unemployment from the domestic economy to the foreign one). This increase in domestic wealth $\left(W_{t} \uparrow\right)$ can appreciate the currency $\left(S_{t} \downarrow\right)$ through the following variables.

1. It can raise domestic expenditure by increasing domestic consumption:

$$
C_{t}=f\left(W_{t}\right)
$$

where, $C_{t}=$ consumption and $W_{t}=$ domestic wealth.

Then, aggregate demand ( $A D=C+I+G+X-M)$ will increase, which will affect production $(Q)$ and income $(Y)$. This higher income will increase the demand for money $\left(M_{t}^{d}\right)$.

2. It can raise the demand for domestic money directly if wealth enters the money demand function: ${ }^{7}$

$$
M_{t}^{d}=\alpha_{0}+\alpha_{1} W_{t}+\alpha_{2} P_{t}-\alpha_{3} i_{t}+\varepsilon_{t}
$$

where, $M_{t}^{d}=$ demand for money, $P_{t}=$ price level, $i_{t}=$ nominal interest rate (opportunity cost of capital), and $\varepsilon_{t}=$ the error term.

3. If domestic bonds and foreign bonds are imperfect substitutes, domestic residents have a greater tendency to hold wealth in the form of domestic

\section{Source: Economagic.com}

7 The estimation of eq. (5) is as follows:

$$
\begin{gathered}
m_{t}=-3.386^{\text {**** }}+0.029^{* * *} r d j i a_{t}+2.271^{* * * *} p_{t}-0.017^{\text {**** }} i_{t}+1.453^{\text {**** }} \varepsilon_{t-1}+\ldots+0.372^{\text {**** }} \varepsilon_{t-6} \\
\left.R^{2}=0.258\right) \quad(0.012) \quad(0.050) \quad(0.003) \quad(0.061)
\end{gathered}
$$

where, $\quad r d j i a=$ real DJIA (real wealth), $p_{t}=\ln$ of CPI, and $i_{t}=\mathrm{S}$-T interest rate (3-month T-Bills rate). 
bonds; then, the increase in domestic wealth will raise the demand for domestic bonds:

$$
\begin{gathered}
+ \\
B_{t}^{d}=f\left(W_{t}\right)
\end{gathered}
$$

where, $B_{t}^{d}=$ demand for domestic bonds.

We assume that there are no barriers segmenting international capital markets, but we have imperfect capital substitutability, which means that there is a risk premium $\left(R P_{t}\right)$,

$$
R P_{t}=f d_{t}-E\left(\Delta s_{t}\right)=i_{t}-i_{t}^{*}-E\left(\Delta s_{t}\right)=\left(f_{t}-s_{t}\right)-\left(s_{t+1}^{e}-s_{t}\right)
$$

where, $R P_{t}=$ risk premium, $f d_{t}=$ forward discount, $E\left(\Delta s_{t}\right)=$ expected change in the spot exchange rate, $i_{t}-i_{t}^{*}=$ interest rate differential, $s_{t}=\ln$ of the spot exchange rate, and $f_{t}=\ln$ of the forward exchange rate.

Thus, investors allocate their bond portfolia between the two countries in proportions that are functions of the expected rates of return $\left(i_{t}^{e}\right.$ and $\left.i_{t}^{* e}\right)$. The two assets are imperfect substitutes because there are differences between the two countries in liquidity, in monetary policy, in tax rates, in default risk, in political risk, in exchange rate risk, in the structure of the economy, and in other factors. We assume that there are perfect international bond markets and the two bonds differ, due to their currency denomination (one is in dollars and the other is in a foreign currency).

A shock in the economy, in the form of a change in wealth, produces a wealth effect, which is an increase in the demand for each financial asset, and a substitution effect, substituting a high return financial asset for the low return alternative. Consequently, the exchange rate and interest rates have to adjust to ensure portfolio equilibrium. The portfolio balance approach states that the exchange rate and interest rates are determined simultaneously by the portfolio equilibrium conditions for asset holders in these two different countries.

\section{A Theoretical Model}

The portfolio-balance approach is based on the following assumptions: (1) The purchasing power parity (PPP) does not hold because goods are not identical in the two countries. (2) The uncovered interest parity (UIP) does not hold. (3) The exchange rate is expected to be unchanged. (4) Only three assets are available for investment for each domestic household: money, domestic bonds, and foreign bonds. (5) Bonds are not perfect substitutes. (6) It assumes perfect capital mobility without capital controls and similar barriers to investment. (7) It assumes narrow transaction costs and high completion in the money markets. (8) The size of the 
domestic economy is relatively small, so it cannot have any effect on the foreign rate of interest.

A simple version of the portfolio balance model can be presented with the following equations:

Demand for money:

$$
M_{t}^{d}=m\left(i_{t}, i_{t}^{*}, W_{t}\right)
$$

Demand for domestic bonds:

$$
B_{t}^{d}=b\left(i_{t}, i_{t}^{*}, W_{t}\right)
$$

Demand for foreign bonds evaluated in the domestic currency:

$$
S_{t} B_{t}^{* d}=f\left(i_{t}, i_{t}^{*}, W_{t}\right)
$$

The supply of these assets is given as follows: $M_{t}^{s}, B_{t}^{s}$, and $B_{t}^{* s}$, and we assume equilibria,

$$
\begin{aligned}
& M_{t}^{d}=M_{t}^{s}=M_{t} \\
& B_{t}^{d}=B_{t}^{s}=B_{t} \\
& B_{t}^{* d}=B_{t}^{* s}=B_{t}^{*}
\end{aligned}
$$

where, $B_{t}^{d}=$ demand for bonds, $B_{t}^{s}=$ supply of bonds, $B_{t}=$ the equilibrium amount of bonds, and an asterisk $(*)$ denotes the foreign variable.

The financial portfolio makes up the total wealth $\left(W_{t}\right)$, which is equal to the sum of the three assets,

$$
W_{t}=M_{t}+B_{t}+S_{t} B_{t}^{*}
$$

At any point in time, the existing stocks of these assets are fixed and the domestic interest rate $\left(i_{t}\right)$ and exchange rate $\left(S_{t}\right)$ must adjust so that the assets are willingly held by investors (maximization of their return). The stocks of financial assets change over time. When the budget deficit ${ }^{8}$ is increasing, the government issues bonds to finance it, which increases the supply of domestic government bonds $\left(B_{t}\right)$.

8 The U.S, National Debt is $\$ 26.759$ trillion and the Budget Deficit is $\$ 3.130$ trillion (9/14/2020), due to this unique global health, economic, and social crisis with the suspicious Wuhan coronavirus. https://www.usdebtclock.org/. See also, Truth in Accounting.

https://www.truthinaccounting.org/about/our_national_debt?gclid=Cj0KCQjwqfz6BRD8ARIsAIX QCf122O 4SPCsu5r1dTqjy1fBhxLLHgZarRUDTEmaxrIut3mU3cH2eXEaAkvoEALw_wcB 
Autonomous growth of money supply (expansionary monetary policy) ${ }^{9}$ or monetization of the government debt (open market purchase) increases the stock of money $\left(M_{t}\right)$. Current account surpluses increase the net domestic holdings of foreign (bonds) assets $\left(B_{t}^{*}\right)$.

Then, the exchange rate $\left(S_{t}\right)$ of the portfolio balance model will be given from eq. (10) and eq. (14), as follows:

$$
S_{t}=s\left(M_{t}, B_{t}, B_{t}^{*}, i_{t}, i_{t}^{*}\right)
$$

The domestic interest rate $\left(i_{t}\right)$ is determined by the Fed (monetary policy) and the U.S. bonds market, as follows:

$$
i_{t}=r\left(M_{t}, B_{t}\right)
$$

\footnotetext{
${ }^{9}$ Our stranger expansionary monetary policy [this zero interest rate policy $\left(\mathrm{i}_{\mathrm{ff}}=0.00 \%\right)$ by the Fed is a disincentive to save because the real return on saving is negative $\left(r_{S}=-\pi\right)$ ] since 2008, it has generated a money supply of $\$ 18.464$ trillion $(9 / 10 / 2020)$ from $\$ 8.131$ trillion in December 2008; a growth by $\$ 10.333$ trillion or $127.08 \%$ ( $10.815 \%$ per annum).

https://fred.stlouisfed.org/series/M2 . For this reason the inflation rate is on the average about, $\pi=10 \%$ p.a., after 2008 .
}

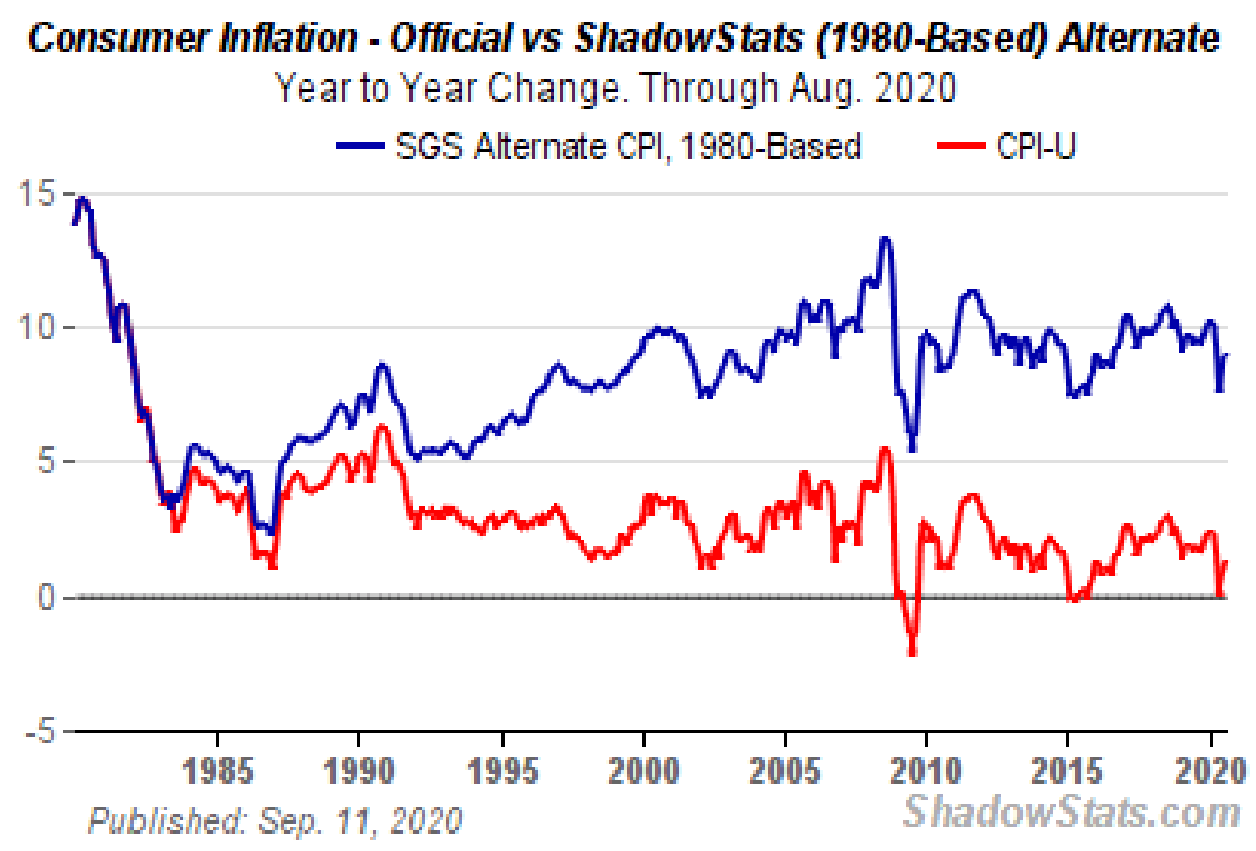

Figure 4: U.S. Inflation Rate

Note: CPI 1980-Based (blue line), SGS inflation rate and CPI-U (red line), official inflation rate. Source: http://www.shadowstats.com/alternate data/inflation-charts 
The foreign interest rate $\left(i_{t}^{*}\right)$ is determined by the foreign central bank and their asset market,

$$
i_{t}^{*}=r\left(M_{t}^{*}, B_{t}^{*}\right)
$$

Substituting eq. (17) into eq. (15), we have,

$$
\begin{gathered}
+\quad-\quad++ \\
S_{t}=s\left(M_{t}, B_{t}, M_{t}^{*}, B_{t}^{*}, i_{t}, i_{t}^{*}\right)
\end{gathered}
$$

Equation (18) specifies the relationship between exchange rates, assets supplies (money and bonds), and interest rates (returns) in the two countries.

1. An expansionary monetary policy, as an exogenous increase in money supply ( $M_{t}$ ) means an increase in wealth $\left(W_{t}\right)$, especially after 2008, due to zero deposit $\left(i_{D}=0.05 \%\right)$. The wealth effect leads to excess demand for domestic and foreign bonds. With given foreign interest rate $\left(\bar{i}_{t}^{*}\right)$, excess demand for domestic bonds would raise their price, so the domestic interest rate will fall. The excess demand for foreign bonds will increase the demand for foreign currency (foreign currency will appreciate), leading to a depreciation of the domestic currency (spot rate will increase).

$$
\begin{aligned}
& M^{s} \uparrow \Rightarrow W \uparrow \Rightarrow E X D B \& B^{*} \Rightarrow \bar{i}^{*} \Rightarrow P_{B} \uparrow \Rightarrow i \downarrow ; \\
& E X D B^{*} \Rightarrow D_{\text {euro }} \uparrow \Rightarrow \text { euro } \uparrow \& \$ \downarrow \Rightarrow S \uparrow
\end{aligned}
$$

2. An increase in domestic government bonds $\left(B_{t}\right)$ will increase the domestic wealth and through a wealth effect, would increase the demand for foreign bonds and consequently, the demand for foreign currency will go up. This will lead to an appreciation of the foreign currency and a depreciation of the domestic currency. Also, an increase in domestic debt $\left(D_{t}\right)$ will increase the supply of bonds, which will reduce their price and increase the domestic interest rate. This higher domestic interest rate $\left(i_{t}>i_{t}^{*}\right)$ would make foreign bonds less attractive. If this substitution effect dominates the previous wealth effect, the domestic currency will appreciate, due to increase in investment on domestic bonds.

$$
\begin{aligned}
& B \uparrow \Rightarrow W \uparrow \Rightarrow B^{* d} \uparrow \Rightarrow D_{\text {euro }} \uparrow \Rightarrow \text { euro } \uparrow \& \$ \downarrow \Rightarrow S \uparrow \\
& D \uparrow \Rightarrow B^{s} \uparrow \Rightarrow P_{B} \downarrow \Rightarrow i \uparrow \Rightarrow B^{* d} \downarrow \Rightarrow B^{d} \uparrow \Rightarrow \$ \uparrow \Rightarrow S \downarrow
\end{aligned}
$$


3. An increase, now, in net holdings of foreign bonds $\left(B_{t}^{*}\right)$, induced by a current account surplus $(C A>0)$, increases the domestic wealth. This wealth effect will increase the demand for domestic assets, which will increase their prices and the interest rate will fall. This will depreciate the domestic currency (exchange rate will increase).

$$
C A \uparrow \Rightarrow B^{*} \uparrow \Rightarrow W \uparrow \Rightarrow B^{d} \uparrow \Rightarrow P_{B} \uparrow \Rightarrow i \downarrow \Rightarrow \$ \downarrow \Rightarrow S \uparrow
$$

Based on the theory, these are the expected effects of the independent variables on the spot exchange rate. Eq. (18) gives also the signs of these effects. 


\section{Some Empirical Results}

We test eq. (18) by using data for the U.S. and Australia and the OLS estimation is given in Tables 1 and 2. The data are monthly from 1988:04 until 2019:06 and they are coming from Economagic.com and Bloomberg. They are: $A S_{t}=$ Australian spot rate $(\$ / \mathrm{A} \$), a s_{t}=\ln$ of AS, $M_{t}=\mathrm{U} . \mathrm{S}$. money supply (M2), $B_{t}=\mathrm{U} . \mathrm{S}$. bonds, $i_{t}=$ U.S. 3-month T-Bill rate, $M_{t}^{*}=$ Australian money supply, $B_{t}^{*}=$ Australian bonds, and $i_{t}^{*}=$ Australian interest rate. The outstanding U.S. bonds are shown in the Figure $5^{10}$ and of Australian bonds in Figure $6 .{ }^{11}$

${ }_{10} \mathrm{See}$, https://tradingeconomics.com/united-states/government-bond-yield . Also, https://fred.stlouisfed.org/release?rid=327

Amount Outstanding of Total Debt Securities in Non-Financial Corporations Sector, All Maturities, Residence of Issuer in United States (TDSAMRIAONCUS)

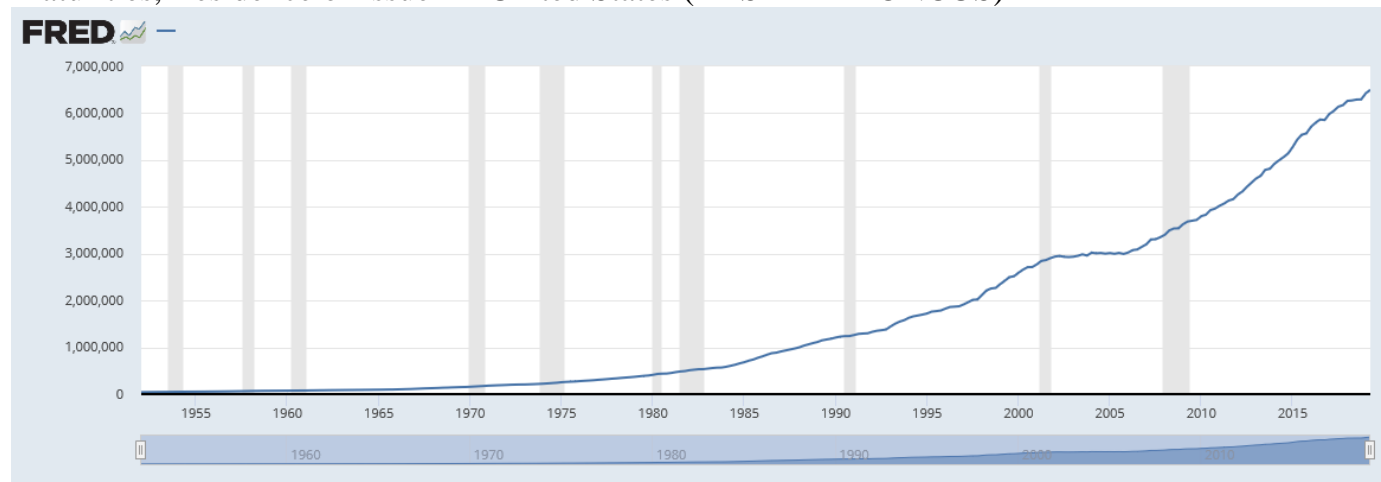

Figure 5: Amount of U.S. Bonds

Source: https://fred.stlouisfed.org/series/TDSAMRIAONCUS

11 Amount Outstanding of Domestic Bonds and Notes in General Government Sector, Long-Term at Original Maturity, Residence of Issuer in Australia (DBNLTRIAOGGAU)

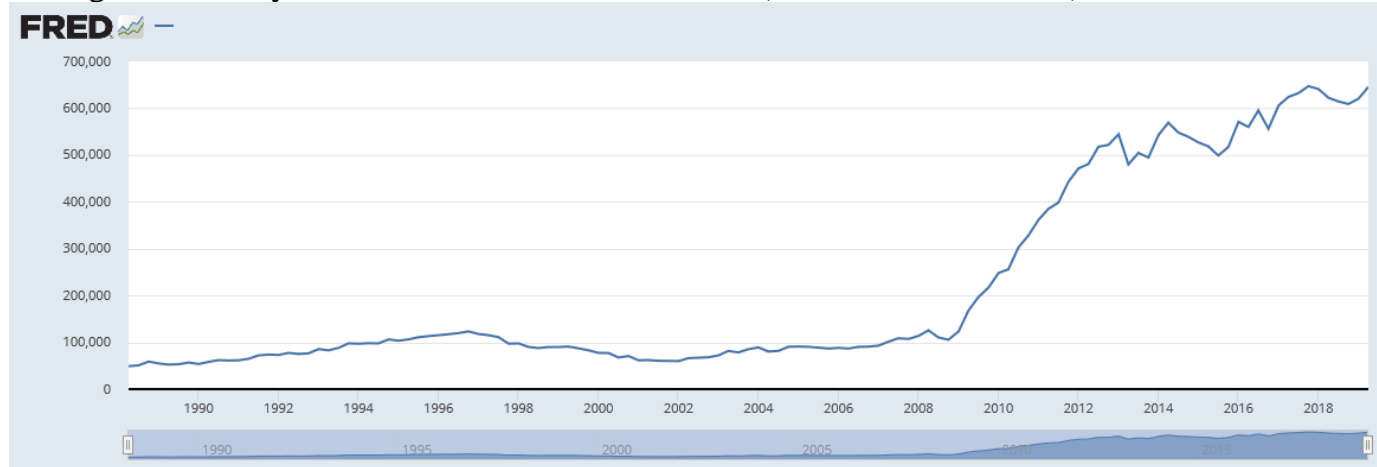

Figure 6: Amount of Australian Bonds

Source: https://fred.stlouisfed.org/series/DBNLTRIAOGGAU 
Table 1: Exchange Rate Determination (Portfolio-Balance Approach) (Short-term Interest Rates)

\begin{tabular}{|c|c|c|c|c|c|}
\hline & $A S_{t}$ & $A S_{t}$ & & $a s_{t}$ & $a s_{t}$ \\
\hline \multirow[t]{2}{*}{$C$} & $1.042^{* * * *}$ & 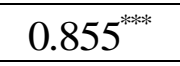 & $c$ & $10.042^{\text {**** }}$ & $6.401^{\text {****** }}$ \\
\hline & $(0.035)$ & $(0.060)$ & & $(0.692)$ & $(0.903)$ \\
\hline \multirow[t]{2}{*}{$M_{t}$} & 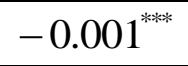 & $-0.001^{* * * *}$ & $m_{t}$ & $-0.715^{\text {**** }}$ & $-0.572^{\text {**** }}$ \\
\hline & $(0.001)$ & $(0.001)$ & & $(0.081)$ & $(0.133)$ \\
\hline \multirow[t]{2}{*}{$B_{t}$} & $-0.001^{\text {**** }}$ & $-0.001^{*}$ & $b_{t}$ & $-0.782^{\text {**** }}$ & $-0.516^{\text {**** }}$ \\
\hline & (0.001) & (0.001) & & $(0.064)$ & $\begin{array}{l}(0.078) \\
\end{array}$ \\
\hline \multirow[t]{2}{*}{$M_{t}^{*}$} & $0.001^{* * * * *}$ & $0.001^{* * * * * * *}$ & $m_{t}^{*}$ & $0.942^{* * * * *}$ & $0.680^{\text {******* }}$ \\
\hline & (0.001) & $(0.001)$ & & $(0.054)$ & $(0.076)$ \\
\hline \multirow[t]{2}{*}{$B_{t}^{*}$} & 0.001 & $0.001^{\text {***** }}$ & $b_{t}^{*}$ & $0.116^{* * * * *}$ & $0.125^{* * * * a}$ \\
\hline & $(0.001)$ & $(0.001)$ & & $(0.011)$ & $(0.015)$ \\
\hline \multirow[t]{2}{*}{$i_{t}$} & $-0.020^{\text {***** }}$ & $-0.022^{* * * * *}$ & $i_{t}$ & $-0.009^{* * *}$ & $-0.016^{\text {******* }}$ \\
\hline & $(0.003)$ & $(0.004)$ & & $(0.004)$ & $\begin{array}{l}(0.005) \\
\end{array}$ \\
\hline \multirow[t]{2}{*}{$i_{t}^{*}$} & $0.011^{\text {**ak }}$ & $0.019^{\text {****** }}$ & $i_{t}^{*}$ & $0.017^{\text {**** }}$ & $0.025^{\text {w*kak }}$ \\
\hline & $(0.002)$ & $(0.003)$ & & $(0.003)$ & $(0.003)$ \\
\hline \multirow[t]{2}{*}{$M A(1)$} & - & $1.551^{\text {*wak }}$ & & - & $1.351^{\text {**** }}$ \\
\hline & & $\begin{array}{l}(0.046) \\
\end{array}$ & & - & $(0.049)$ \\
\hline \multirow[t]{2}{*}{$M A(2)$} & - & $1.608^{\text {*wak }}$ & & - & $1.203^{* * * * *}$ \\
\hline & - & $(0.075)$ & & - & $(0.073)$ \\
\hline \multirow[t]{2}{*}{$M A(3)$} & - & $1.365^{* * * * *}$ & & - & $0.930^{* * * * *}$ \\
\hline & - & $(0.087)$ & & - & $(0.074)$ \\
\hline \multirow[t]{2}{*}{$M A(4)$} & - & $0.866^{* * * *}$ & & - & $0.426^{\text {**** }}$ \\
\hline & & $(0.078)$ & & & \\
\hline \multirow[t]{2}{*}{$M A(5)$} & - & $0.287^{\text {***** }}$ & & - & - \\
\hline & & $(0.049)$ & & & \\
\hline$R^{2}$ & 0.648 & 0.971 & & 0.789 & 0.973 \\
\hline$S S R$ & 2.083 & 0.172 & & 0.077 & 0.282 \\
\hline$F$ & 113.095 & 1010.079 & & 228.902 & 1166.989 \\
\hline$D-W$ & 0.083 & 1.896 & & 0.128 & 1.798 \\
\hline$N$ & 375 & 375 & & 375 & 375 \\
\hline$R M S E$ & 0.074537 & 0.021494 & & 0.076051 & 0.027685 \\
\hline
\end{tabular}


Note: $A S_{t}=$ Australian spot rate $(\$ / A \$), a s_{t}=\ln$ of $A S, C=$ constant term, $M_{t}=$ U.S. money supply (M2), $B_{t}=$ amount of U.S. bonds, $i_{t}=$ U.S. 3-month T-Bill rate, a star (*) on a variable is the foreign variable, a lower case letter is the natural logarithm of the capital $\left[m_{t}=\ln \left(M_{t}\right)\right], M A(1)=$ Moving Average process, $=$ significant at the $1 \%$ level, ${ }^{* *}=$ significant at the $5 \%$ level, ${ }^{*}=$ significant at the $10 \%$ level, $R^{2}=R$-squared, $S S R=$ Sum of Squared Residual, $F=F$-statistic, $D-W=$ Durbin-Watson statistic, and $N=$ number of observations.

Source: Economagic.com and Bloomberg.

Table 2: Exchange Rate Determination (Portfolio-Balance Approach) (Long-term Government Bonds Rates)

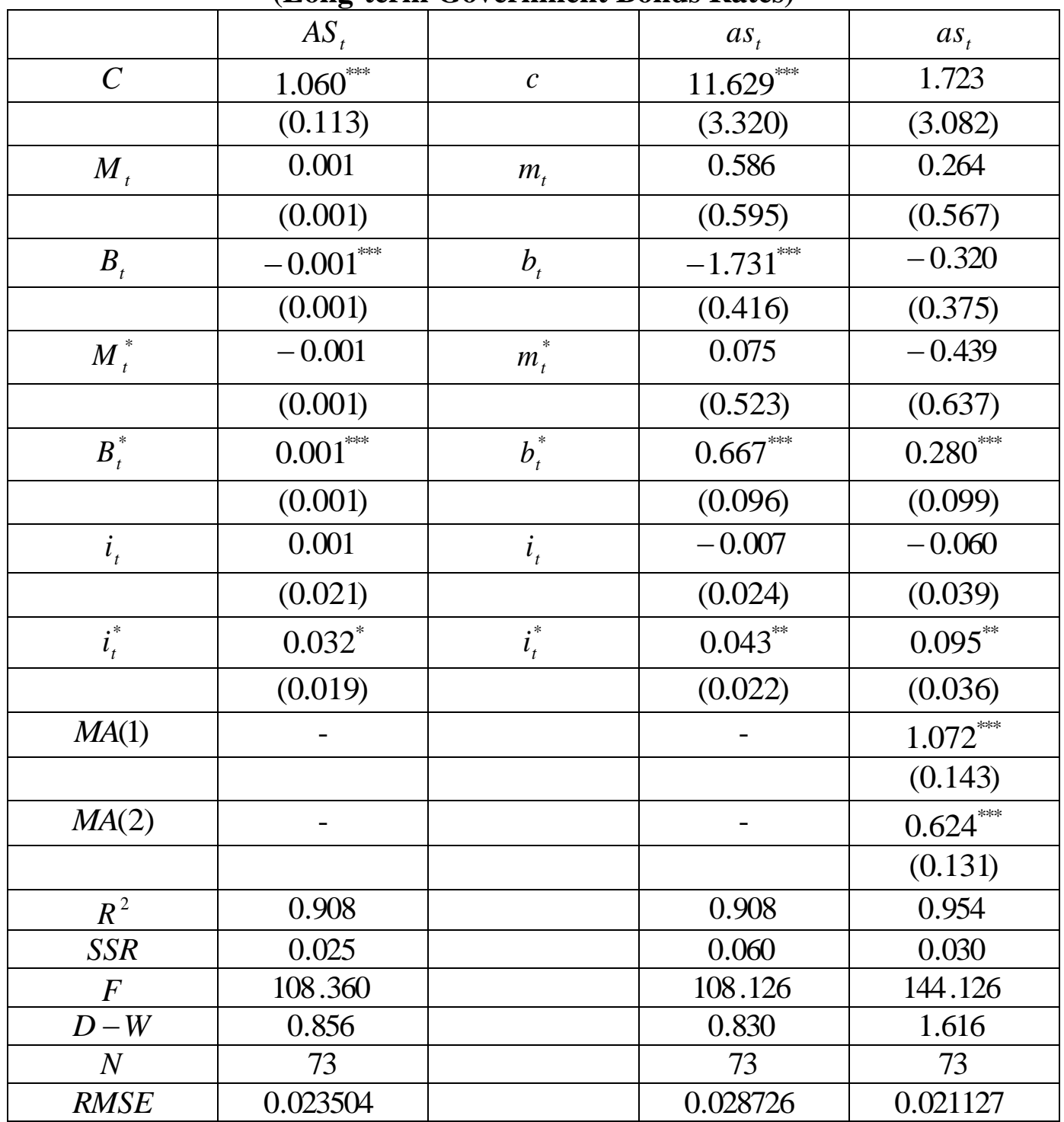


Note: See, Table 1. $i_{t}=$ U.S. 10-year Treasury bonds rate and $i_{t}^{*}=$ Australian 10year government bonds rate.

Source: See, Table 1.

Table 1 gives in its first column the results of eq. (18) by using the spot rate between the U.S. dollar and the Australian dollar (\$/A \$). All coefficients are statistically significant at the $1 \%$ level, except the Australian bonds $\left(B_{t}^{*}\right)$. The interest rates are having also correct signs. The problem with this regression is the low D-W statistic $=0.083$ (serial correlation of the error term). In the second column, we correct the serial correlation of the error term by using MA(1) to MA(5). The D-W became 1.896. This regression gives, now, all coefficients as significant and three of them have correct signs $\left(B_{t}^{*}, i_{t}\right.$, and $\left.i_{t}^{*}\right)$. The results show that the most important variables are the interest rates in the two countries.

Then, we generate the natural logarithms of our variables $\left(a s_{t}=\ln A S_{t}, m_{t}=\ln \right.$ $M_{t}$, etc.), except the interest rates and the results appear in column 3 . All coefficients are statistically significant at the $1 \%$ level, except $i_{t}$, which it is at the $5 \%$ level. The signs are correct for $B_{t}^{*}, i_{t}$, and $i_{t}^{*}$, but the problem is the low D$\mathrm{W}$ statistic $=0.128$. Now, we correct the serial correlation of the error term by using MA(1) to MA(4), and we have improved the $\mathrm{D}-\mathrm{W}=1.798$ and all coefficients are significant at the $1 \%$ level. The signs are correct for $B_{t}^{*}, i_{t}$, and $i_{t}^{*}$. This last regression gives good results and has a small $\mathrm{RMSE}=0.027685$.

Table 2 examines eq. (18) by using the same independent variables, except interest rates; it uses long-term government bonds rates for both countries. The first column is without logarithms of the variables and the coefficients are significant for $B_{t}$, $B_{t}^{*}$, and $i_{t}^{*}$. The signs are correct for $B_{t}^{*}$, and $i_{t}^{*}$. The problem is the low D-W $=$ 0.856 . Then, we run the same equation by using natural logarithms for the variables ( $b_{t}=\ln B_{t}$, etc.). Column two gives the results and significant coefficients of the variables $b_{t}, b_{t}^{*}$, and $i_{t}^{*}$. The signs are correct for $m_{t}, b_{t}^{*}, i_{t}$, and $i_{t}^{*}$, but D-W is low 0.830. After the correction with a MA(1) and MA(2), we have a D-W=1.616, but the only significant coefficient is the $i_{t}^{*}$. Thus, the previous results with shortterm interest rates are better (Table 1, Column 4). 


\section{Conclusion}

The Asset Market Approach (the Monetarist model, the Overshooting model, and the Portfolio-balance approach) assumes that whether foreigners are willing to hold claims in monetary form depends on an extensive set of investment considerations or drivers. These drivers include the following: (1) Relative real interest rates are a major consideration for investors in foreign bonds and short-term money market instruments. (2) Prospects for economic growth and profitability are an important determinant of cross-border equity investment in both securities and foreign direct investment. (3) Capital market liquidity is particularly important to foreign institutional investors. Cross-border investors are not only interested in the ease of buying assets, but also in the ease of selling those assets quickly for fair market value if desired. (4) A country's economic and social infrastructure is an important indicator of that country's ability to survive unexpected external shocks and to prosper in a rapidly changing world economic environment, as it is the current one. (5) Political safety is exceptionally important to both foreign portfolio and direct investors. The outlook for political safety is usually reflected in political risk premiums for a country's securities and for purposes of evaluating foreign direct investment in that country. ${ }^{12}$

(6) The credibility of corporate governance practices is important to cross-border portfolio investors. A firm's poor corporate governance practices can reduce foreign investors' influence and cause subsequent loss of the firm's focus on shareholder wealth objectives. (7) Contagion is defined as the spread of a crisis in one country to its neighboring countries and other countries that have similar characteristics; at least in the eyes of cross-border investors. Contagion can cause an 'innocent' country to experience capital flight with a resulting depreciation of its currency. (8) Speculation can cause a foreign exchange crisis or can make an existing crisis worse.

The Portfolio-Balance Approach provides the following key points: (1) It emphasizes the importance of global financial markets (especially, the bond markets in the two countries). (2) It assumes the existence of arbitrage between these two economies. (3) It offers a realistic, but a very simplistic analysis framework. (4) The portfolio balance approach, based on empirical evidence (U.S. and Australia) has proven as a relatively accurate predictor of exchange rates $\left(R^{2}=\right.$ $0.973, \quad S S R=0.282, \quad F$-statistic $=1,166.989, \quad D-W=1.798$, and $R M S E=$ 0.027685 .

12 Political risk can be eliminated, if firms are producing domestically, which affects positively domestic production, employment, and income. The last 40 years, the outsourcing of manufacturing has caused serious problems to U.S. and Europe and lately, it caused a health, economic, and social crisis, the worst in our economic history, due to the suspicious Chinese coronavirus (the globalization effect). 
Thus, the empirical results, Tables 1 and 2 show that for the exchange rate determination by using the portfolio-balance approach, the \$/A exchange rate, the important variables (significant) are all of them, but correct in signs are $b_{t}^{*}$ (Australian bonds), $i_{t}$ (U.S. T-Bill rate) and $i_{t}^{*}$ (Australian T-Bill rate). Our objective is to use also other assets (i.e., stocks or stock market indexes) and from different countries and to test their effects on the exchange rate by applying these data to the Portfolio-Balance Approach. This might be a future project.

ACKNOWLEDGEMENTS. I would like to acknowledge the assistance provided by William F. Schwalm and Janice Mecadon. Financial support (professional travel expenses, submission fees, etc.) was provided by Provost's Office (Faculty Travel Funds, Henry George Fund, and Faculty Development Funds). The usual disclaimer applies. Then, all remaining errors are mine. 


\section{References}

[1] Arize, Augustine C., Theologos H. Bonitsis, Ioannis N. Kallianiotis, Krishna M. Kasibhatla, and John Malindretos (2000), Balance of Payments Adjustment: Macro Facets of International Finance Revisited, Westport, CT: Greenwood press.

[2] Bhandari, Jagdeep S. and Bluford H. Putnam (1984), Economic Interdependence and Flexible Exchange Rates, Cambridge, MA: The MIT Press.

[3] Bilson, John (1978), "Rational Expectations and the Exchange Rate", in The Economics of Exchange Rates, Edited by J. Frenkel and H.G. Johnson, Reading MA: Addison-Wesley.

[4] Branson, W. H. and H. Halttunen (1979), "Asset Market Determination of Exchange Rates: Initial Empirical and Policy Results", in Trade and Payments under Flexible Exchange Rates, Martin, J. P. and A. Smith (eds.), pp. 55-85, London: Macmillan.

[5] Branson, W. H., H. Halttunen, and P. Masson (1977), "Exchange Rates in the Short Run: The Dollar-Deutschemark Rate", European Economic Review, 10, pp. 303-324.

[6] Canto, Victor A. and Marc A. Miles (1984), "Exchange Rates in a Global Monetary Model with Currency Substitution and Rational Expectations", in Economic Interdependence and Flexible Exchange rates, edited by J. S. Bhandari and B. H. Putnam, Cambridge, MA: The MIT Press, pp. 157-175.

[7] Chiang, T. (1991), "International Asset Pricing and Equity Market Risks", Journal of International Money and Finance, 10, September, pp. 365-391.

[8] Cushman, David O. (2007), "A portfolio balance approach to the CanadianU.S. exchange rate", Review of Financial Economics, Vol. 16, Issue 3, pp. 305320.https://onlinelibrary.wiley.com/doi/full/10.1016/j.rfe.2006.06.001

[9] Dornbusch, Rudiger (1978), "Monetary Policy under Exchange Rate Flexibility", in Managed Exchange-Rate Flexibility: The Recent Experience, Federal Reserve Bank of Boston Conference Series, No. 20.

[10] Dornbusch, Rudiger (1976), "Expectations and Exchange rate Dynamics", Journal of Political Economy, 84 (6), December, pp. 1161-1176.

[11] Enders, Walter (1995), Applied Econometric Time Series, New York, N.Y.: John Wiley \& Sons, Inc.

[12] Engle, Robert F. and C. W. J. Granger (1987), "Co-integration and Error Correction: Representation, Estimation, and Testing", Econometrica, 55, pp. 251-276.

[13] Fama, E. (1970), "Efficient Capital markets: A Review of Theory and Empirical Work", Journal of Finance, 25, May, pp. 383-417.

[14] Frenkel, Jacob A. (1984), "Flexible Exchange Rates, Prices, and the Role of 'News': Lessons from the 1970s", in Economic Interdependence and Flexible Exchange Rates, edited by J. S. Bhandari and B. H. Putnam, Cambridge, MA: The MIT Press, pp. 3-41. 
[15] Frenkel, Jacob A. and Michael L. Mussa (1980), "The Efficiency of Foreign Exchange Markets and Measures of Turbulence", American Economic Review, 70, pp. 374-381.

[16] Ghosh, Satyajit and Ioannis N. Kallianiotis (2012), "Uncertainty, Oil Prices, Debts, Deficits, and Exchange Rates Dynamics", unpublished manuscript, University of Scranton, June, pages 24.

[17] Giovannini, A. and Philippe Jorion (1987), "Interest Rates and Risk Premia in the Stock Market and in the Foreign Exchange Market", Journal of International Money and Finance, 6 (1), March, pp. 107-124.

[18] Hodgson, Douglas J., Oliver Linton, and Keith Vorkink (2004), “Testing Forward Exchange Rate Unbiasedness Efficiently: A Semiparametric Approach", Journal of Applied Economics, VII (I), May, pp. 325-353.

[19] Isard, Peter (1980), "Expected and Unexpected Changes in Exchange Rates: The Role of Relative Price Levels, Balance-of-Payments Factors, Interest Rates and Risk", Federal Reserve Board, International Finance Discussion Papers, No. 156.

[20] Kallianiotis, John N. (2019a), Foreign Exchange Rates and International Finance, Hauppauge, N.Y.: Nova Science Publishers, October 2019, ISBN: 978-1-53616-550-0.

https://novapublishers.com/shop/foreign-exchange-rates-and-internationalfinance/

[21] Kallianiotis, I.N. (2019b), "Monetary Policy: Is the Dual Mandate of the Fed Maximizing the Social Welfare?" International Journal of Economics and Financial Research, Vol. 5, No. 6, June, pp. 112-142. https://arpgweb.com/journal/5/archive/06-2019/6/5, https://arpgweb.com/pdf-files/ijefr5(6)112-142.pdf

[22] Kallianiotis, I.N. (2019c), "Monetary Policy, Real Cost of Capital, Financial Markets, and the Real Economic Growth", Journal of Applied Finance \& Banking, Vol. 9, No. 1, pp. 75-118.

http://www.scienpress.com/journal_focus.asp?main_id=56\&Sub_id=IV\&Issu $\underline{\mathrm{e}=810815}$ http://www.scienpress.com/Upload/JAFB/Vol\%209_1_4.pdf

[23] Kallianiotis, John N. (2018a), The European Union and its Debt Crises: The Deception of the Greeks, Hauppauge, N.Y.: Nova Science Publishers, August, ISBN: 978-1-53614-067-5. https://novapublishers.com/shop/the-europeanunion-and-its-debt-crises-the-deception-of-the-greeks/

[24] Kallianiotis, I.N. (2018b), "How Efficient is the Foreign Exchange Market?", Athens Journal of Business and Economics, Volume 4, Issue 3, July, pp. 293-326. http://www.athensjournals.gr/ajbe/v4i3 and http://www.athensjournals.gr/business/2018-4-3-4-Kallianiotis.pdf

[25] Kallianiotis, I.N. (2018c), "Exchange Rate Expectations", Journal of Applied Finance \& Banking, Vol. 8, Issue 2, March, pp. 101-134. http://www.scienpress.com/journal_focus.asp?main_id=56\&Sub_id=IV\&Issu $\underline{\mathrm{e}=519551}$ http://www.scienpress.com/Upload/JAFB/Vol\%208_2_5.pdf 
[26] Kallianiotis, I.N. (2018d), "Exchange Rate Dynamics: The Overshooting Model (with Sticky Prices)", International Journal of Economics and Financial Research, Vol. 4, Issue 2, pp. 38-45.

https://arpgweb.com/pdf-files/ijefr4(2)38-45.pdf https://arpgweb.com/?ic=journal\&journal $=5 \&$ info $=$ archive \& month $=02-$ $2018 \&$ issue $=2 \&$ volume $=4$

[27] Kallianiotis, J. N. (2017), "Central Banks, Monetary Policy, and their Efficiency", (Chapter 1) in Monetary Policy: Perspectives, Strategies and Challenges, Harriet Ward (editor), New York: Nova Science Publishers.

[28] Kallianiotis, J.N. (2013), Exchange Rates and International Financial Economics: History, Theories, and Practices, Palgrave Macmillan, October, pages 312, ISBN: 978-1-137-28322-1.

[29] Kallianiotis, Ioannis N. (1988), "A Theoretical Monetary and Real Approach to the Balance of Payments", Greek Economic Review, 10(2), December, pp. 383-404.

[30] Khan, Aima and Zaheer Abbas (2015), "Portfolio balance approach: An empirical testing", Journal of Economics and International Finance, Vol. 7(6), June, pp. 137-143.

[31] Krueger, Anne O. (1983), Exchange-Rate Determination, Cambridge Surveys of Economic Literature, New York: Cambridge University Press.

[32] Krugman, Paul (1984), "Oil and the Dollar", in Economic Interdependence and Flexible Exchange Rates, edited by J. S. Bhandari and B. H. Putnam, Cambridge, MA: The MIT Press, pp. 179-190.

[33] Mishkin, Frederic S. (1983), A Rational Expectations Approach to Macroeconomics: Testing Policy Ineffectiveness and Efficient-Markets Models, National Bureau of Economic Research, Chicago: The University of Chicago Press.

[34] Muth, J. F. (1961), "Rational Expectations and the Theory of Price Movements", Econometrica, 29, pp. 315-335.

[35] Neely, Christopher and Lucio Sarno (2002), "How Well Do Monetary Fundamentals Forecast Exchange Rates?", Review, The Federal Reserve Bank of St. Louis, September/October, pp. 51-72.

[36] Phillips, P. C. B. and P. Perron (1988), "Testing a Unit Root in Time Series Regression", Biometrika, 75, pp. 335-346.

[37] Tucker, Alan L, Jeff Madura, and Thomas C. Chiang (1991), International Financial Markets, St. Paul, MN: West Publishing Company.

[38] Wang, Peijie (2009), "The Portfolio Balance Approach to Exchange Rate Determination" In: The Economics of Foreign Exchange and Global Finance. Springer, Berlin, Heidelberg, pp. 215-239. https://link.springer.com/content/pdf/10.1007\%2F978-3-642-00100-0_10.pdf https://doi.org/10.1007/978-3-642-00100-0_10 